\title{
ZASADY WYNAGRADZANIA W SPORCIE W KONTEKŚCIE IDEI SPRAWIEDLIWOŚCI I RÓWNOŚCI PŁCI
}

\section{WSTEP}

W sierpniu 2010 r., podczas zorganizowanego w Gdańsku maratonu „Solidarności” mężczyźni otrzymali dwukrotnie wyższe nagrody finansowe niż kobiety. W regulaminie zawodów znajdował się zapis, iż za pierwszą lokatę w kategorii generalnej organizator płaci mężczyznom 10 tysięcy złotych, a kobietom - 5 tysięcy złotych. Panowie mieli zapewnione nagrody do ósmego miejsca, a panie tylko do szóstego; za ostatnie premiowane miejsce kobieta dostała 500 złotych, a mężczyzna - 1,2 tysiąca złotych ${ }^{1}$. Dyskusja dotycząca tej sprawy przypomina nieco debatę, która przetoczyła się przez światowe media 3 lata wcześniej, gdy po raz pierwszy przyznano równe nagrody finansowe w wielkoszlemowych turniejach tenisowych Wimbledon i Roland Garros $^{2}$.

Potraktowanie sportu jak każdej innej sfery życia publicznego pozwala na wpisanie zróżnicowania nagród finansowych w ogólnospołeczny trend zróżnicowania zarobków kobiet i mężczyzn. Pojawia się jednak pytanie, czy takie spojrzenie jest uprawnione, czy nie należy potraktować sportu, jako sfery, która rządzi się swoimi własnymi regułami i która każe przyjąc inną perspektywę rozpatrywania wymiaru finansowego. Opierając się na tych debatach, chciałabym podjąć próbę odpowiedzi na dwa pytania: 1) za co przyznawane sa nagrody finansowe czy - mówiąc ogólniej - według jakiej logiki wynagradzane są osiągnięcia sportowe, 2) czy obowiązująca w sporcie logika wynagradzania jest sprawiedliwa $\mathrm{z}$ punktu widzenia równości płci?

\footnotetext{
1 M. Jałoszewski, Bieg „Solidarności” - kobietom ptacimy połowe, „Metro” z 22 sierpnia 2010 r., http://wiadomosci.gazeta.pl/ (31.08.2010).

${ }^{2}$ Podczas najważniejszych turniejów tenisowych zawodniczki przez długi czas otrzymywały niższe nagrody finansowe niż mężczyźni. Najwcześniej, gdyż już (?) w 1973 r., wyrównano nagrody w turnieju US Open. Po jedenastu latach, czyli w 1984 r., organizatorzy Australian Open podjęli podobną decyzję, mimo to w latach 1996-2000 mężczyźni otrzymywali wyższe nagrody, a ich realne wyrównanie nastąpiło dopiero w 2000 r. (zob. np. B. Smart, The Sport Star. Modern Sport and Cultural Economy of Sporting Celebrity, London 2005, s. 169 i n.). Warto jednak zauważyć, że w wielu turniejach, rozgrywanych osobno dla każdej z płci, utrzymane zostały zróżnicowane nagrody.
} 


\section{ZA CO PRZYZNAWANE SA NAGRODY SPORTOWE}

Niektórzy uważają, że nagrody powinny być proporcjonalne do wysiłku włożonego w osiągnięcie zwycięstwa. Argumentem najczęściej przytaczanym przez przeciwników zrównania finansowych nagród $\mathrm{w}$ tenisie jest mniejszy wysiłek, jaki muszą włożyć zawodniczki w wygranie meczu. W zawodach kobiet do wygrania meczu wystarcza dwa zwycięskie sety, natomiast w przypadku mężczyzn - podczas turniejów wielkoszlemowych - musza to być trzy sety. W konsekwencji mecze kobiet sa z reguły krótsze i - według niektórych - mniej pasjonujące, natomiast mecze mężczyzn trwaja zdecydowanie dłużej, w wypadku 5-setowego pojedynku nawet kilka godzin. Argument ten można jednak łatwo zakwestionować, porównując tenis do innych dyscyplin sportu, w których kryterium długości spotkania nie decyduje o wysokości nagród.

Przeświadczenie, że większy wysiłek powinien pociągá za sobą większe zyski, również nie znajduje swojego odzwierciedlenia w innych dyscyplinach. Rafał Stec pisze: „w sporcie wysokość płacy rzadko zależy wyłącznie od czasu lub wysiłku poświęconego pracy”. Swoją wypowiedź ilustruje następującym przykładem: „Adam Małysz pokonuje na nartach sto metrów i nawet nie zdąży się spocić, ale nikt nie powie, że powinien zarabiać wielokrotnie mniej od wiecznie zdyszanej Justyny Kowalczyk, która przemierza kilometry i przed meta przestaje niekiedy $\mathrm{z}$ wycieńczenia widzieć” ${ }^{3}$. Natomiast $\mathrm{w}$ niektórych dyscyplinach, podobnie jak $\mathrm{w}$ tenisie, zróżnicowane $\mathrm{w}$ zależności od płci zawodników sa , techniczne” aspekty ich rozgrywania, na przykład wysokość zawieszenia siatki czy kosza, ciężar kuli, dystans biegu, co jednak nie przekłada się na zróżnicowanie nagród finansowych. Najlepszym tego przykładem są duże imprezy lekkoatletyczne, w tym mistrzostwa świata, igrzyska olimpijskie czy prestiżowe cykle Diamentowej Ligi, podczas których nagrody są albo równe dla obu płci, albo przyznawane niezależnie od kryterium płci - dla najlepszej osoby w rywalizacji sportowej.

Drugim uzasadnieniem dla różnic finansowych pomiędzy zawodniczkami a zawodnikami są różnice w ich osiągnięciach sportowych. Kryje się za tym przekonanie, że najwyższe nagrody powinni otrzymywać ci, którzy są - niezależnie od płci - najlepsi. A ponieważ kobiety z reguły nie są tak dobre jak mężczyźni, więc nie powinny tyle samo zarabiać. Byłaby to analogiczna sytuacja do różnic finansowych między pierwszą a druga ligą, na przykład piłkarską. W ten sposób myślenia wpisuje się wypowiedź Kazimierza Zimnego, organizatora maratonu Solidarności: „,w przyszłym roku stawki nagród moga zostać ujednolicone, ale pod warunkiem, że zawodniczki będą szybciej biegać!"”. Uważa on również, że kobiety otrzymały nagrody tylko dlatego, że stworzono dla nich odrębną klasyfikację, ponieważ w kategorii open najlepsza kobieta była na 11, niegwarantującej nagrody, pozycji. Podobny pogląd reprezentuje jeden

${ }^{3}$ R. Stec, Sport - misja dla feministek najtatwiejsza, http://rafalstec.blox.pl (9.03.2011).

${ }^{4}$ Cyt. za: M. Jałoszewski, op. cit. 
z autorów komentarzy dotyczących artykułu o maratonie, który pisze: „Jeśli kobiety nie moga szybciej biegać, to ich sprawa. Przypomnieć warto, że postulatem feministek jest »taka sama płaca za TAKA SAMA pracę«. Skoro tak, to z jakiej racji domagają się takiej samej nagrody za GORSZY wynik?" ${ }^{5}$.

Jeśli przyjęlibyśmy taką logikę, wedle której wynagradzamy tych, którzy są najlepsi, to można by się zastanowić, czy czarnoskórzy biegacze, głównie Kenijczycy, nie powinni w związku z tym dostawać wyższych nagród finansowych w maratonach niż biali mężczyźni. Być może oprócz kategorii otwartej, należałoby stworzyć osobną kategorię dla białych mężczyzn? Niestety, nie ma miejsca w tym artykule na szerszą dyskusję dotyczącą kwestii (nie)zróżnicowania rasowego $\mathrm{w}$ sporcie, warto jednak - myśląc o rozdziale płci - pamiętać o braku takiego podziału w wypadku ras.

Trzecim uzasadnieniem zróżnicowania nagród finansowych jest coś, co można określić jako w a g a m ed alu. Zarówno w wypadku biegów, jak i tenisa zwraca się uwagę na mniejszą konkurencję wśród kobiet, która - jak można wywnioskować z przytaczanych argumentów - świadczy o mniejszej wartości kobiecych osiągnięć. Wygrana mężczyzny zostaje wyżej wyceniona dlatego, iż zwycięzca musiał pokonać większą liczbę przeciwników. Znów można się odwołać do słów Kazimierza Zimnego, który mówi: „To nie jest równy sport. W tegorocznym maratonie pobiegło 480 mężczyzn, a kobiet tylko 26 "6 . O mniejszej konkurencji wśród kobiet, choć nie w kontekście nierówności finansowej, pisze również S. Socha, który zauważa, że na poziomie olimpijskim kobietom łatwiej jest odnieść sukces, właśnie ze względu na mniejsza konkurencję wynikająca $\mathrm{z}$ małej obecności w wielu dyscyplinach kobiet pochodzących z Azji, Afryki czy Ameryki Południowej ${ }^{7}$.

I wreszcie czwartym argumentem uzasadniającym, według uczestników dyskusji, zróżnicowanie nagród jest podporządkowanie sportu regułom rynkowym i medialnym. Ich zdaniem, skoro nagrody finansowe sa fundowane przez prywatnych sponsorów, to mają oni prawo decydować o tym, na co i na kogo chca przeznaczyć swoje pieniądze. Ten argument doprowadza nas do niezwykle istotnego wątku finansowania współczesnego sportu i jego uzależnienia od praw rynku.

\section{PODPORZĄDKOWANIE REGUŁOM RYNKOWYM}

Wśród najlepiej zarabiających sportowców dominują mężczyźni, zwłaszcza golfiści, tenisiści, koszykarze, piłkarze i bokserzy. W 2010 r. najwięcej (105 milionów dolarów) zarobił - pomimo skandali dotyczących jego życia prywatnego - Tiger Woods, drugie miejsce na liście zajął bokser Floyd Mayweather (65 milionów dolarów), a trzecie - koszykarz Kobe Bryant

\footnotetext{
${ }^{5}$ Komentarz czytelników do: M. Jałoszewski, loc. cit. (29.04.2011).

${ }^{6}$ Cyt. za: ibidem (31.08.2010).

7 S. Socha, Sport kobiet w Polsce: potrzeby a rzeczywistość, ,Sport Wyczynowy” 2005, nr 1-2, s. 22.
} 
(z zarobkami wysokości 48 milionów dolarów) ${ }^{8}$. W wypadku polskich zawodników najwięcej w 2010 r. zarobili startujący w zagranicznych zespołach: Robert Kubica (25 milionów złotych), Marcin Gortat (prawie 18 milionów złotych) oraz Sebastian Janikowski (12 milionów złotych), a za nimi na liście znalazło się sześciu piłkarzy ${ }^{9}$.

Nawet największe gwiazdy kobiecego sportu, o relatywnie wysokich zarobkach w obrębie swojej płci, zarabiają znacznie mniej niż mężczyźni. W tym samym 2010 r. najwięcej wśród kobiet zarobiły tenisistki: Maria Szarapowa (24,5 milionów dolarów), Serena Williams (20,2 milionów dolarów) oraz jej siostra - Venus (15,4 milionów dolarów). Warto zauważyć, że zarobki pierwszej na liście najbogatszych zawodniczek, Marii Szarapowej, stanowią mniej więcej 1/4 zarobków Tigera Woodsa, i są o prawie 14 miliona dolarów niższe niż klasyfikowanego na dziesiątym miejscu sportowca mężczyzny. Na polskiej liście, obejmującej setkę najbogatszych sportowców, znalazły się tylko cztery kobiety, pierwsza z nich - Justyna Kowalczyk z zarobkami ponad 4 milionów złotych znajduje się na niej na 13 miejscu.

Czy różnice w zarobkach zawodniczek i zawodników można uzasadnić, opierając się na wyróżnionych wcześniej kryteriach? Wydaje się, że nie do końca, a tym, co odgrywa tu główną rolę, jest podporządkowanie sportu regułom rynkowym. Oblicze współczesnego sportu i rządzące nim zasady są kształtowane w dużej mierze przez dwa, nierozerwalnie ze sobą powiązane, zjawiska medializację i komercjalizację. Jak twierdzi Andrzej Gwóźdź: ,[...] nie ma dziś sportu bez mediów, ale i nie ma mediów bez sportu”, zawody sportowe stają się dzisiaj przede wszystkim widowiskami medialnymi, w których porządek mediów zaczyna dominować nad porządkiem zawodów sportowych ${ }^{10}$.

Telewizja buduje popularność poszczególnych dyscyplin sportowych wyrażoną poprzez tzw. oglądalność, która legitymizuje zróżnicowanie płci w wymiarze finansowym. W wypadku wspólnie rozgrywanych zawodów, jak na przykład w lekkiej atletyce czy podczas turniejów Wielkiego Szlema, trudno jednoznacznie rozstrzygnąć, która z płci pracuje w większym stopniu na konto sponsorów i organizatorów. Być może z tego właśnie powodu obowiązują tu podobne zasady finansowe. Jednak, jak zauważa Stec, „kiedy obie płcie sa rozdzielone czasem i przestrzenią, rozdziela je też otchłanna nierówność wynagrodzenia. Piłkarze zarabiają więcej od piłkarek, koszykarze od koszykarek, kolarze od kolarek. Zarabiają dziesięć, pięćdziesiąt, a niekiedy i sto razy więcej" ${ }^{11}$.

Głównym czynnikiem decydującym o zróżnicowaniu zarobków jest popularność samego zawodnika, jak również uprawianej przez niego dyscypliny sportu. Niekoniecznie są nim natomiast osiągnięcia sportowe, rynek bowiem nie

${ }^{8}$ The Forbes List of The World's 50 Top-Earning Athletes, http://www.topendsports.com (30.04.2011).

${ }^{9}$ Ztota setka 2010 - najlepiej zarabiajacy polscy sportowcy, http://gwizdek24.se.pl (20.04.2011).

${ }^{10}$ A. Gwóźdź, Media - eros - przemoc, Kraków 2003, s. 7. Por. H. Jakubowska, Sport jako pole (re)produkowania różnicy ptciowej, w: T. Sahaj (red.). Pogranicza wspótczesnego sportu. Ujęcie społeczne, Poznań 2009.

11 R. Stec, loc. cit. 
zawsze nagradza najlepszych sportowców. Jak pisze na swoim blogu R. Stec: „,najwięcej zarabiaja ci sportowcy, których wyczyny chce podziwiać najwięcej ludzi. Decyduje, jak w całym show-biznesie, oglądalność" ${ }^{12}$. Ilustruje to na przykład porównanie zarobków Justyny Kowalczyk z zarobkami piłkarzy. Jeszcze w 2009 r. mistrzyni świata z Liberca zarobiła ,,jedynie” 800 tysięcy złotych, czyli połowę tego, co Euzebiusz Smolarek (1,6 miliona złotych) i mniej niż ,,wiecznie kontuzjowany” Łukasz Garguła (1,2 miliona złotych) ${ }^{13}$. Różnice te nie mają wyłącznie związku z odmiennością płci, co ilustruje dopiero 98 miejsce w 2010 r. z zarobkami w wysokości 700 tysięcy złotych kulomiota Tomasza Majewskiego, mistrza olimpijskiego, który w analizowanym roku został wicemistrzem Europy i zajął trzecie miejsce w prestiżowym cyklu mityngów Diamentowej Ligi. Należy zwrócić uwagę również na to, że zarobki są zróżnicowane w obrębie jednej dyscypliny uprawianej przez osoby tej samej płci, a nawet w obrębie jednego zespołu. Najlepszym tego przykładem jest piłka nożna: każdy z zawodników podpisuje indywidualny kontrakt.

Popularność zawodników daje im również możliwość powiększania ich dochodów poprzez podpisywanie licznych kontraktów sponsorskich. Co ciekawe, stanowią one w wielu wypadkach większą część dochodów niż te wynikające bezpośrednio z udziału w rozgrywkach sportowych. Choć to głównie zawodniczki postrzega się przez pryzmat ich urody czy seksapilu, co przekłada się często na eksponowanie w mediach ich kobiecego ciała, to ich zarobki z reklam są często mniejsze niż zarobki sportowców. Takim przykładem medialnej i sportowej ikony ostatnich lat jest David Beckham, którego dochody uzyskane $\mathrm{z}$ reklam były dwa razy wyższe niż zarobki za grę w klubach piłkarskich Manchester United i Real Madryt ${ }^{14}$. Sytuacja ta nie dotyczy jednak tylko sportowców, którzy są uznawani za ideały męskości, ale także czołowych, najbardziej rozpoznawalnych zawodników, którzy tych ideałów nie ucieleśniają ${ }^{15}$. Dobrym przykładem jest tutaj Leo Messi, uznawany za jednego z najlepszych piłkarzy na świecie, który w sezonie 2009/2010 zarobił 14 milionów euro za grę w piłkę (10 milionów za grę w Barcelonie oraz 4 miliony za wygrana w Champions League), ale aż 19 milionów euro dzięki kontraktom reklamowym ${ }^{16}$.

\section{IV. „KOBIECE” I „MĘSKIE” SPORTY}

Kryterium oglądalności, przekłada się nie tylko na zróżnicowanie zarobków pojedynczych zawodników i zawodniczek, ale również na dofinansowanie całych dyscyplin. Na sport dziewcząt i kobiet przeznaczane są mniejsze fundusze niż

12 Ibidem.

13 Justyna biedna przy kopaczach, http://www.tvn24.pl (30.04.2011).

${ }^{14}$ B. Smart, The Sport Star. Modern Sport and Cultural Economy of Sporting Celebrity, London 2005, s. 77.

${ }^{15}$ Zob. H. Jakubowska, Medialne wizerunki sportowego ciała - (re)konstrukcja gender?, w: J. Bator, A. Wieczorkiewicz (red.), Ucieleśniania II, Warszawa 2008.

${ }^{16}$ Gwiazdor Barcelony jest wspierany i sowicie opłacany przez takie marki, jak: Adidas, Pepsi-Cola, Gillette, Gatorade, Konami, Air Europa, Telefonica/Movistar, SportCenter/ESPN, Damm, Danone, Storkman, SanDisk, Mirage/Seiko, Lody czy Repsol YPF (M. Chłopaś, Wśród piłkarzy najlepiej zarabia Messi, ,Dziennik” z 25 marca 2010 r., http://wiadomosci.dziennik.pl; 30.04.2011). 
na sport chłopców i mężczyzn. Wśród przyczyn tego stanu rzeczy J. Coakley wskazuje między innymi na mniejszy dochodowy potencjał sportu kobiet, który przekłada się na gorszę ocenę $\mathrm{w}$ oczach sponsorów ${ }^{17}$. Sporty, w których dominują kobiety, na przykład łyżwiarstwo figurowe czy gimnastyka artystyczna, cieszą się mniejszą popularnością. Tymczasem sporty uprawiane wyłącznie lub częściej przez mężczyzn, na przykład w Stanach Zjednoczonych tak zwana wielka czwórka (czyli koszykówka, baseball, piłka nożna i hokej na lodzie), cieszą się największym zainteresowaniem widzów. W konsekwencji większość funduszy przeznaczanych na sport służy wspieraniu i promowaniu niewielkiej liczby dyscyplin, podczas gdy o wiele mniejsze dofinansowanie sportów niszowych, często zresztą niezależnie od płci, sprawia, iż nie mają one szansy przesunąc się w kierunku sportowego centrum ${ }^{18}$. Zatem mamy tutaj do czynienia z błędnym kołem: niszowy charakter sportu uzasadnia brak jego finansowania, co jednocześnie utrwala jego niszowy charakter. Ponieważ są to często sporty „,kobiece”, tym samym podtrzymywana jest męska dominacja.

Umacnia ją również minimalne dofinansowanie udziału kobiet $\mathrm{w}$ definiowanych jako „męskie” dyscyplinach, co bardzo dobrze ilustruje przykład piłki nożnej. Informacja o tym, że FIFA tylko jedną dziesiątą swoich wpływów przeznacza na piłkę nożną kobiet ${ }^{19}$, pokazuje te dysproporcje, ale stają się one jeszcze bardziej widoczne, gdy przyjrzymy się codziennym doświadczeniom zawodniczek. O polskich piłkarkach czytamy: „Same sobie piora koszulki i cieszą się, że akurat wśród kobiet nie ma zwyczaju wymieniania ich po meczu, bo z każdej muszą się dokładnie rozliczyć.” Ewa Żyła, piłkarka klubu AZS Wrocław i reprezentantka Polski, w tym samym artykule mówi: „Gdy grałyśmy o Puchar UEFA w Niemczech, dowiedziałam się, że kluczowe zawodniczki w najlepszych zespołach tamtejszej ligi zarabiają sześć, siedem tysięcy euro miesięcznie. A ja byłabym szczęśliwa, gdybym na czysto dostawała dwa tysiące złotych” i dalej: „Nasza kadra narodowa i męska reprezentacja Polski to dwa zupełnie różne światy. Kiedyś na zgrupowaniu dostałyśmy ortaliony. Były za duże i używane. Wszystko zrozumiałam, gdy odczytałam nazwiska zapisane markerem na metkach. Hajto, Kryszałowicz, Krzynówek. Dostałyśmy ciuchy, które kiedyś nosili faceci, ale nie były już im potrzebne" ${ }^{20}$.

Obok mniejszych funduszy przeznaczanych na „kobiece” sporty i minimalnego dofinansowania udziału kobiet w „męskich” sportach, problemem jest także kwestia nierównych środków finansowych przeznaczanych na dyscypliny popularne wśród obu płci. Na przykład średnia pensja w kobiecej amerykańskiej lidze koszykówki (WNBA) stanowi jedynie 2 procent średniej z męskiej ligi $(\mathrm{NBA})^{21}$. Wyższe wynagrodzenia mężczyzn są $\mathrm{w}$ tym wypadku uzasadniane tym, że mężczyźni na nie zarabiają. Ich rozgrywki przyciągają większą liczbę

17 J. Coakley, Sports in Society. Issues and Controversies, New York 2007, s. 243-244.

${ }_{18}$ M. Messner, Taking a Field. Women, Men and Sports, Minnesota 2002, s. 76.

19 T. Sahaj, Kobiety na boisku i widowni. ,Sport Wyczynowy” 2006, nr 5-6, s. 52.

${ }^{20}$ Cytat za: A. Bugajski, R. Opiatowski, Nic co meskie nie jest im obce, ,,Magazyn Sportowy”, nr 3(17) z 16 stycznia 2009 r., s. 17.

${ }^{21}$ Women, Gender Equality and Sport, December 2007, http://www.un.org, s. 77. 
kibiców, którzy więcej wydają na bilety, co wpływa na podpisywanie bardziej lukratywnych kontraktów reklamowych czy telewizyjnych.

\section{SPRAWIEDLIWOŚĆ I RÓWNOŚĆ PŁCI?}

Według Simony Giordano i Johna Harrisa, nierówności finansowe w sporcie należy rozważać jedynie w wymiarze ekonomicznym, gdyż to on w dzisiejszym silnie zmedializowanym i skomercjalizowanym sporcie odgrywa decydująca rolę ${ }^{22}$. Czy jednak powinniśmy rozpatrywać kwestie finansowe także w szerszym społecznym i etycznym kontekście? Można, moim zdaniem, wskazać na przynajmniej dwa takie konteksty: 1) sprawiedliwość społeczną, 2) równość płci. Pytanie brzmiałoby zatem: czy obowiązująca w sporcie logika wynagradzania, bazująca $\mathrm{w}$ dużej mierze na prawach rynku, jest sprawiedliwa $\mathrm{z}$ punktu widzenia równości płci? Istotne jest, moim zdaniem, również przyjrzenie się temu, jak wpisuje się ona w dyskurs o różnicy płci legitymizowany, w wypadku sportu, różnicami natury biologicznej.

Próbując odpowiedzieć na to pytanie, warto sięgnąć do klasycznego już artykułu Jane English Sex Equity in Sports (1978). Autorka dokonuje w nim rozróżnienia na podstawowe (basic) i rzadkie (scarce) dobra wynikające z uprawiania sportu. Do pierwszych zalicza zdrowie, zabawę i satysfakcję związaną $\mathrm{z}$ poprawianiem swoich rezultatów oraz radość $\mathrm{z}$ przebywania w grupie. Sa one związane $\mathrm{z}-\mathrm{z}$ założenia dostępnym dla wszystkich - sportem amatorskim. Przykładem drugiego rodzaju korzyści są sława, rozpoznawalność i nagrody finansowe. Do nich, w odróżnieniu od pierwszych, nie każdy ma prawo. Według autorki, powinny one zależeć od umiejętności bądź poziomu reprezentowanego przez sportowca, w praktyce jednak często stanowią odzwierciedlenie wpływu rynku ${ }^{23}$. Główne pytanie, które stawia sobie J. English to: w jaki sposób powinny być rozdzielane te korzyści, jeśli naszym celem jest zagwarantowanie równych szans dla kobiet w sporcie? Autorka proponuje dwa rozwiązania, z których pierwsze odnosi się do sportu o charakterze rekreacyjnym, w którym - jak uważa - należy zmienić system dystrybuowania zasobów w taki sposób, aby większe kwoty przeznaczane były na sport kobiet. Pozwoli to zapewnić lepsze zaplecze i możliwości treningowe dla kobiet, a tylko to da im szanse stania się profesjonalistkami i czerpania zysków z zawodowego uprawiania sportu.

O ile pierwsza propozycja przedstawiona przez J. English nie budzi większych kontrowersji, o tyle druga wywołała polemikę. Autorka uważa bowiem, że dostęp do ograniczonych dóbr nie powinien zależeć od wyników czy popularności danej dyscypliny, lecz być zgodny z zasadą równości dla najważniejszych grup społecznych. Taki sposób myślenia jest trudny do

\footnotetext{
${ }^{22}$ S. Giordano, J. Harris, What is Gender Equality in Sports, w: C. Tamburrini, T. Tännsjö (red.), Genetic Technology and Sport. Ethical Questions, New York 2005, s. 214.

${ }^{23}$ J. English (1978), za: C. Tamburrini, T. Tännsjö, The Genetic Design of a New Amazon, w: C. Tamburrini, T. Tännsjö (red.), op. cit., s. 184.
} 
przyjęcia, zakłada bowiem nie tyle wyrównanie możliwości, czy inaczej mówiąc - warunków początkowych, ile wyrównywanie wynagrodzeń niezależnie od osiaganych rezultatów. Pierwszą propozycję można uznać za zgodną z marksistowską teorią, zgodnie z która dystrybucja zasobów jest niesprawiedliwa, jeśli wynika z nierównej dystrybucji szans/możliwości. Przesunięcie części środków ze sportu mężczyzn na rozwój sportowego zaplecza (,,́rodki produkcji” sportu) i edukację sportową kobiet byłoby w tym wypadku wyrównywaniem szans. Niekoniecznie akceptowalne byłoby jednak przeznaczenie tych funduszy na zwiększenie wynagrodzeń zawodniczek ${ }^{24}$.

Takie rozwiązanie mogłoby zostać uznane za niesprawiedliwe z punktu widzenia mężczyzn. W tym wypadku można odwołać się do zasad sprawiedliwości dystrybutywnej, zgodnie z którymi każdemu należy się to, na co sobie zasłużył, czyli rozkład korzyści powinien być proporcjonalny do włożonego wkładu. Zatem to mężczyźni powinni osiagać większe korzyści, to bowiem ich „,produkty” (rozgrywki) generują większe pieniądze. Według S. Giordano i J. Harrisa, nie ma nic niesprawiedliwego w fakcie, że publiczność woli piłkę nożną mężczyzn od piłki nożnej kobiet ${ }^{25}$. To, że liczniejsza publiczność i popularność sportu przyciagga większą liczbę sponsorów, a w konsekwencji przynosi wyższe zyski finansowe, wpisuje się - zdaniem tych autorów - w logikę systemu apitalistycznego, w którym ceny i korzyści finansowe zależą w dużej mierze od równowagi pomiędzy popytem a podażą. Redystrybucja zasobów, polegająca na przekazaniu kobietom części dochodów wypracowanych przez mężczyzn, stałaby zatem w sprzeczności z rządzącymi sportem zasadami rynkowymi.

\section{WYNAGRADZANIE BIOLOGICZNYCH PREDYSPOZYCJI}

Kolejnym pytaniem, które nasuwa się w rozważanym kontekście jest to, czy zakładane różnice biologiczne między kobietami a mężczyznami, które w wielu dyscyplinach (jak można sądzić między innymi na podstawie rekordów należących do obu płci) dają tym drugim przewagę w sporcie, powinny przekładać się na zróżnicowanie korzyści. Odwołując się na przykład do koncepcji Johna Rawlsa, można uznać to za niesprawiedliwe, osiągnięte zyski czy korzyści wynikają bowiem $\mathrm{z}$ arbitralnej dystrybucji naturalnych cech i umiejętności i w tym sensie nie sa one zasługa jednostki ${ }^{26}$. Chociaż wrodzone cechy nie powinny decydować o wysokości udziału w dzielonych nagrodach, to tak właśnie dzieje się w sporcie profesjonalnym. Mężczyznom przypadają większe korzyści z powodu cech fizjologicznych umożliwiających im osiąganie lepszych wyników $\mathrm{w}$ sporcie.

Być może zatem słuszne byłoby odwołanie się do drugiej zasady sprawiedliwości J. Rawlsa, zgodnie z którą nierówności społeczne i ekonomiczne powinny przynosić korzyści grupom najbardziej upośledzonym ${ }^{27}$. Za taką grupę

\footnotetext{
${ }^{24}$ Por. ibidem, s. 186.

25 S. Giordano, J. Harris, op. cit., s. 214.

${ }^{26}$ J. Rawls, Teoria sprawiedliwości, Warszawa 1994.

27 Ibidem, s. 415.
} 
w kontekście sportu, mając na uwadze twierdzenia o ich gorszych fizycznych predyspozycjach, można uznać kobiety. Zgodnie z ta koncepcja, redystrybucja dochodów od osób bardziej uzdolnionych do osób mniej zdolnych służyłaby sprawiedliwości, słuszne byłoby zatem przekazanie części zasobów dotąd przeznaczanych dla sportowców mężczyzn na dofinansowanie sportowców kobiet. Problemem jednak jest to, na co zwracaja uwagę C. Tamburrini i T. Tännsjö, że nie wszyscy mężczyźni sytuują się na najbogatszym krańcu kontinuum zarobków w sporcie, podobnie jak nie wszystkie kobiety sytuują się na jego najuboższym krańcu ${ }^{28}$. Jeśli zatem chcielibyśmy zastosować tę zasadę, redystrybucja zasobów niekoniecznie powinna odbywać się zgodnie z „logiką płci”, ale z logika płac.

J. English przyjmuje, że istniejące biologiczne różnice między płciami, które predestynuja osoby odmiennej płci do różnych dyscyplin sportowych, przekładają się na brak ich równego udziału w konkurencjach sportowych. Uważa więc, że powinno się stworzyć pewne alternatywne sporty, w których znaczenie będa odgrywały kobiece predyspozycje i to one zostaną odpowiednio wynagrodzone ${ }^{29}$. Dzisiejszy sport pozwala jednak dość łatwo zakwestionować przypisanie na podstawie cech biologicznych kobiet i mężczyzn do różnych dyscyplin, o czym świadczy między innymi rosnący udział kobiet w sportach tradycyjnie definiowanych jako „męskie”. Ciągle jednak aktualny pozostaje podział opierający się na kulturowych kategoriach kobiecości i męskości, stąd - jak można przypuszczać - wypływa propozycja C. Tamburriniego i T. Tännsjö ${ }^{30}$. Autorzy ci uważaja, że najlepszym rozwiązaniem, zarówno dla sportu, jak i społeczeństwa, byłaby pozytywna dyskryminacja osób, które angażuja się $\mathrm{w}$ dyscypliny sportowe niekojarzone tradycyjnie $\mathrm{z}$ dana płcią. Oznaczałoby to większe finansowe wsparcie kobiet uprawiających „męskie” dyscypliny, a mniejsze sportów „kobiecych” i - analogicznie - przeznaczanie mniejszych kwot pieniężnych dla mężczyzn uprawiających „męskie” sporty przy wzroście wsparcia dla zawodników zaangażowanych $\mathrm{w}$ dyscypliny zdominowane przez kobiety.

\section{FINANSOWA DYSKRYMINACJA KOBIET}

Niezależnie od kontrowersji związanych z konkretnymi rozwiązaniami proponowanymi przez J. English, należy docenić, że zwróciła ona uwagę na potrzebę rozpatrzenia finansowego zróżnicowania w sporcie w kontekście nierówności płci. To, że problem ten pozostaje nadal aktualny, świadczy reakcja środowisk kobiecych na informacje dotyczące nagród finansowych w omawianym już maratonie „,Solidarności”. Magdalena Środa uznała zróżnicowanie tych nagród za „klasyczny seksizm, wręcz głupotę” i stwierdziła,

${ }^{28}$ C. Tamburrini, T. Tännsjö, op. cit., s. 185. Interesujące byłoby rozważenie tego samego zagadnienia z punktu widzenia płci, ale -jak już wcześniej sygnalizowałam - wykracza to poza ramy tego artykułu.

${ }^{29}$ Ibidem, s. 184.

${ }^{30}$ Ibidem, s. 185. 
że „organizatorzy powinni być zdymisjonowani” ${ }^{31}$. Z kolei Marika Lisowska, regionalna szefowa Partii Kobiet, zauważyła, że nierówne finansowe traktowanie kobiet i mężczyzn jest niezgodne z konstytucyjną zasadą równości i skierowała $\mathrm{w}$ tej sprawie list protestacyjny do organizatorów, pisząc $\mathrm{w}$ nim między innymi: „Czym różni się wysiłek biegnących kobiet od biegnących obok mężczyzn? Nie sposób zgodzić się z pomysłem nagradzania kobiet połową kwoty przyznawaną mężczyznom, sprzecznym z postanowieniem punktu $7 \S 6$ rozdział I Statutu NSZZ »Solidarność«, a także art. 32 i 33 Konstytucji Rzeczypospolitej Polskiej. [...] znak »Solidarność« zobowiązuje, to nie może być puste słowo i tym bardziej taki zapis w regulaminie jest krzywdzący i oburzający" ${ }^{32}$. Partia Kobiet rozważała również skierowanie sprawy do sądu i Rzecznika Praw Obywatelskich. Nie wiadomo, jak sprawa ta zostałaby rozstrzygnięta przez sąd. Odwołując się do sprawy sądowej dotyczącej skoków narciarskich ${ }^{33}$, można przypuszczać, że sąd uznałby, iż zawody sportowe rządzą się swoimi własnymi prawami i nie podlegaja prawu państwowemu. To bowiem organizatorom przysługuje przywilej ustalania regulaminu, który - jak mówi K. Zimny „mamy prawo ustalić, jak chcemy” ${ }^{34}$.

Osoby najbardziej zainteresowane, czyli same uczestniczki maratonu, które zabrały głos $\mathrm{w}$ tej sprawie, również uznały nierówne nagrody za przejaw dyskryminacji. Arleta Meloch, który wygrała w kategorii kobiet, stwierdziła, iż - co prawda - „decydując się na udział w maratonie wiedziałam, jaki jest regulamin, że są różnice w wysokości nagród dla mężczyzn i kobiet”, ale dodała, że: „kiedy odbierałam nagrodę, w głębi duszy poczułam się niedoceniona. Przecież pokonałam ten sam dystans, co mężczyźni. Biegliśmy razem, każdy $\mathrm{z}$ nas męczył się w tym samym upale". Marta Jeschke, medalistka mistrzostw Europy w sztafecie, stwierdza natomiast wprost: „To dyskryminacja, przecież kobiety wkładają w ten maraton taki sam wysiłek jak mężczyźni, powinny być więc tak samo doceniane" 35 .

Nadanie rozgłosu konkretnym sprawom dotyczącym zróżnicowania finansowego $\mathrm{w}$ sporcie i uznanie ich za przejaw nierówności płci $\mathrm{w}$ ogóle przyczynia się, jak można sądzić, do wprowadzania pozytywnych - z punktu widzenia kobiet - rozwiązań. Świadczy o tym zarówno zrównanie wysokości nagród w turniejach Wielkiego Szlema, jak i zmiana regulaminu w maratonie „Solidarności”. Choć K. Zimny początkował mówił dziennikarzom, że „,te baby zwariowały, czy co? Nie dajmy się oczarować” ${ }^{36}$, to po kilku dniach zmienił

31 Cyt. za: M. Jałoszewski, loc. cit. (31.08.2010).

${ }^{32}$ Cyt. za: A. Kozłowska, Partia Kobiet oprotestowała regulamin Maratonu, „Gazeta Wyborcza. Trójmiasto" z 23 sierpnia 2010 r., http://trojmiasto.gazeta.pl/trojmiasto (31.08.2010).

${ }^{33}$ W 2009 r. wobec decyzji o nierozgrywaniu zawodów skoków narciarskich kobiet podczas igrzysk w Vancouver 15 zawodniczek skierowało do sądu sprawę przeciwko ich organizatorowi, twierdząc, że jej wprowadzenie w życie będzie naruszeniem zasady równości płci. Sąd najwyższy prowincji Kolumbia Brytyjska orzekł, iż do dyskryminacji - co prawda - doszło, ale państwo nie może ingerować w decyzje podejmowane przez MKOL, któremu podlega komitet organizacyjny. Tym samym przepisy obowiązujące podczas igrzysk nie moga być uznane za łamanie zasady równości płci zapisanej w konstytucji.

${ }^{34}$ Cyt. za: A. Kozłowska, op. cit.

35 Ibidem.

${ }^{36}$ Cyt. za: Ł. Konarski, Maraton NieSolidarności: Jest wniosek do RPO. „Powariowaty te baby?”, „Gazeta Wyborcza” z 23 sierpnia 2010 r., http://www.tokfm.pl (30.08.2010). 
jednak zdanie i wydał oświadczenie o następującej treści: „Zarząd Stowarzyszenia Maratonu »Solidarność« oświadcza że w związku z oprotestowaniem wysokości nagród dla kobiet w XVI ENERGA Maratonie »Solidarności« podjął decyzję o zmianie pkt. »NAGRODY« w regulaminie biegu na przyszłe lata. Wszystkie uczestniczki, które poczuły się niedowartościowane finansowo - PRZEPRASZAMY [pisownia oryginalna - H.J.] i zapraszamy za rok!!!!!! Dyrektor maratonu Kazimierz Zimny" ${ }^{37}$.

\section{ZAKOŃCZENIE}

Czy zróżnicowanie finansowe w sporcie jest sprawiedliwe z punktu widzenia równości płci? Próbując odpowiedzieć na to pytanie, należy wyraźnie rozróżnić dwie kwestie: stwarzanie warunków do uprawiania sportu oraz nagradzanie sportowców. W pierwszym wypadku równość płci powinna być - moim zdaniem - utrzymana i jej brak jest przejawem niesprawiedliwości. Przeznaczanie większych funduszy na rozwój sportu chłopców i mężczyzn niż na rozwój dziewcząt i kobiet stawia te drugie na przegranej pozycji. Kobiety rywalizujące w sporcie mają ciągle mniejsze wsparcie niż mężczyźni, i to zarówno ze strony administracyjnej (nie bez znaczenia jest też z pewnością niedoreprezentowanie kobiet w gremiach zarządzających sportem), jak i społecznej, czego przyczyną jest wspomniana niejednokrotnie w tym artykule oglądalność. Uzasadnieniem tego może być zarówno powszechne postrzeganie sportu jako męskiego dominium, jak i krótsza tradycja sportu kobiet przekładająca się na mniejszą popularność zawodów kobiet. Jest to jednak temat szerszy, który wykracza poza ramy tego artykułu.

Argumentem sprzyjającym zwiększeniu dofinansowania sportu kobiet, obok zasady równości płci, powinno być też to, że - jak wskazują dane statystyczne dotyczące na przykład medali zdobytych podczas igrzysk olimpijskich zawodniczki sa niezwykle cenne dla reprezentacji narodowych. Odwołując się do ostatnich letnich igrzysk olimpijskich w Pekinie, można stwierdzić, że na sukces państw, które zajęły najwyższe miejsca w tabeli medalowej, składają się w dużej mierze medale zdobyte przez kobiety. Jak zauważa S. Socha, kraje, które przoduja w sporcie kobiecym, dominuja zazwyczaj w sporcie $\mathrm{w}$ ogóle, a ,żaden kraj nie może liczyć na wysoką pozycję w światowej, w tym także olimpijskiej rywalizacji bez sukcesów w sporcie kobiet" ${ }^{38}$.

Wydaje się, że kwestia stwarzania równych warunków początkowych dla sportu kobiet i mężczyzn nie budzi większych wątpliwości, co nie oznacza, iż jest wcielana w życie. Inaczej sprawa wygląda w wypadku nagradzania sportowców za ich osiagnnięcia. Uznanie zróżnicowania finansowego za sprawiedliwe bądź niesprawiedliwe zależy od tego, za jakimi zasadami wynagrodzeń się opowiadamy, za co, naszym zdaniem, sportowcy powinny być wynagradzani.

\footnotetext{
${ }^{37}$ Cyt. za: Szef Maratonu Solidarności przeprasza kobiety, „Gazeta Wyborcza. Trójmiasto” z 25 sierpnia 2010 r., http://wiadomosci.gazeta.pl (30.08.2010).

38 S. Socha, op. cit., s. 18-20.
} 
Argumentem przemawiającym za podziałem zawodów na rozgrywki kobiet i mężczyzn są zróżnicowane predyspozycje fizjologiczne kobiet i mężczyzn, uniemożliwiające im wspólne, sprawiedliwe rozgrywanie zawodów ${ }^{39}$. Uważa się bowiem, że w wypadku większości dyscyplin tylko wówczas, gdy kobiety startuja w swoim własnym gronie, mają szanse na medale, natomiast wspólne starty kobiet i mężczyzn oznaczałyby niesprawiedliwa, niezgodną z zasadami sportu i z zasadami fair play przewagę. Podobne zasady obowiązują w wypadku wspólnie rozgrywanych zawodów, jak na przykład podczas maratonów, podczas których wprowadza się odrębne klasyfikacje dla kobiet i mężczyzn. Jeśli ten podział płci uznamy za słuszny, to wydaje mi się, że sprawiedliwie, czyli równe, powinny być przyznawane nagrody. Uznajemy bowiem, że zwycięzca był najlepszy w swojej kategorii, niezależnie, czy dotyczy to mężczyzn, kobiet, juniorów czy seniorów.

Jedną z głównych trudności związanych z zasadą równości płci w sporcie jest zmiana proporcji w finansowaniu inicjatyw sportowych, gdyż wobec malejących funduszy państwowych coraz większe znaczenie uzyskuje prywatne finansowanie. Akceptując ten zastrzyk finansowy, równocześnie jednak traci się możliwość wymuszania równego traktowania sportu kobiet i mężczyzn. Prywatne podmioty, w przeciwieństwie do instytucji państwowych, nie musza bowiem przestrzegać zasad równości płci. Jej przestrzeganie stałoby często w sprzeczności z mechanizmem rynkowym, który każe wynagradzać tych, którzy przynoszą największe zyski. A są nimi najczęściej mężczyźni uprawiający tradycyjnie „męskie” sporty. Czy w takim razie możliwe jest pogodzenie zasady sprawiedliwości i równości? Najbardziej trafne wydaja się te rozwiązania, które zmienią oblicze samego sportu oraz sposób jego postrzegania przez pryzmat tradycyjnie definiowanych kategorii kobiecości i męskości. Wpisuje się $\mathrm{w}$ to zarówno propozycja C. Tamburriniego i T. Tännsjö, jak i - postulowane przez uchwałe Parlamentu Europejskiego ${ }^{40}$ - zniesienie podziału na tak zwane „męskie” i „kobiece” dyscypliny sportu.

Być może należałoby również rozważyć, brzmiącą z pozoru mało poważnie, propozycję R. Steca, który twierdzi, że w celu zniwelowania dysproporcji finansowych w sporcie ,wystarczy uświadamiać same kobiety. Im więcej z nich sport pokocha, tym lepszy będzie los ich idolek. Telewizje będą się wdzięczyć w przetargach o transmisje, zaślinią się sponsorki, urokowi żeńskich igrzysk nie oprą się reklamodawczynie" ${ }^{41}$. Wydaje się, że zwiększenie zainteresowania sportem ze strony kobiet, które przełożyłoby się na większą oglądalność i popularność sportu, mogłoby w konsekwencji doprowadzić do większego finansowego wsparcia sportu. Pod warunkiem że kobiety interesowałyby się sportem kobiet, a nie sportem mężczyzn, gdyż zwiększyłoby to raczej, niż zniwelowało, nierówności finansowe.

Warto jednak zauważyć, że sponsorzy zmieniaja swoje nastawienie do sportu kobiet. Będąc poza kontrolą instytucji państwowych, nie moga pozostać obojętni na sygnały płynące ze strony społeczeństwa i dokonujące się w wymiarze społeczno-kulturowym przemiany. Odpowiedzią na nie jest zarówno coraz

\footnotetext{
${ }^{39}$ Choć od tej zasady istnieją nieliczne wyjątki, jednym z nich jest jeździectwo.

${ }^{40}$ Uchwała Parlamentu Europejskiego w sprawie udziału kobiet w sporcie z 2003 r.

${ }^{41}$ R. Stec, op.cit.
} 
częstsze podpisywanie kontraktów sponsorskich z indywidualnymi zawodniczkami, jak i wzrost zainteresowania sponsorów kobiecymi rozgrywkami, co dobrze ilustruje przykład siatkówki. Według danych firmy Polkomtel, wartość medialna siatkówki kobiet wzrosła od 54,7 w 2007 r. do 253,3 miliona złotych w 2009 r., a łącznie siatkówka kobiet i mężczyzn ma aktualnie większą wartość medialną niż najpopularniejsza dyscyplina sportowa, czyli piłka nożna ${ }^{42}$.

Kwestie finansowe, jak - mam nadzieje - pokazał ten artykuł, są bardzo ściśle powiązane z kwestiami płci. Rozważanie sportu w szerszym kontekście: społecznym, kulturowym czy etycznym, pozwala analizować je również w ramach takich zagadnień, jak równość czy sprawiedliwość. Trudno rozstrzygnąć jednoznacznie, które z kryteriów - ekonomiczne czy płci - jest priorytetowe w sporcie. Wydaje się, że pewne rozwiązania podyktowane są przede wszystkim względami ekonomicznymi, a kwestie płci odgrywaja w nich znaczenie drugorzędne. Z drugiej jednak strony, niektóre z różnic finansowych wynikaja z ,ugenderowienia” sportu jako instytucji. Problemem do rozstrzygnięcia pozostaje to, jak pogodzić, w imię równości i sprawiedliwości, te dwa wymiary.

\author{
dr Honorata Jakubowska \\ Uniwersytet im. Adama Mickiewicza w Poznaniu \\ honorata@amu.edu.pl
}

\title{
RULES OF REWARDING IN SPORTS IN THE CONTEXT OF IDEAS OF THE JUSTICE AND GENDER EQUALITY
}

\author{
Summary
}

Two debates concerning the amount of financial awards in sport are a starting point for the presented paper. One of them concerns the Solidarity marathon of 2010, and the other the decision of equalizing the prize money during Roland Garros and Wimbledon tennis competitions in 2007. Based on both debates, I am trying to answer two questions: (i) what is the prize money a reward for or, more generally, what are the rules of rewarding in sports and (ii) whether the rules of rewarding are just and fair from the point of view of the equality of the genders. I am also considering how these rules fit to the discourse of the sexual difference sanctioned, in the case of sport, by the differences of biological nature. In the paper I refer to both, i.e., the phenomena shaping contemporary sport (commercialisation and medialisation), and the theoretical conceptions (such as Rawls' theory of justice), or the already classical article by Jane English 'Equity Sex in Sports' published in 1978.

\footnotetext{
${ }^{42}$ Dane zaprezentowane przez Bogusławę Matuszewską, wiceprezes zarządu firmy Polkomtel, podczas konferencji „Kobieta i sport”, zorganizowanej przez Polskie Stowarzyszenie Sportu Kobiet 29 listopada 2010 r. w Warszawie.
} 
